\title{
The Rise and Fall of Employee Ownership in Estonia, 1987-2001
}

\author{
Kalmi, Panu
}

Document Version

Final published version

Publication date:

2003

\section{License \\ CC BY-NC-ND}

Citation for published version (APA):

Kalmi, P. (2003). The Rise and Fall of Employee Ownership in Estonia, 1987-2001.

Link to publication in CBS Research Portal

\section{General rights}

Copyright and moral rights for the publications made accessible in the public portal are retained by the authors and/or other copyright owners and it is a condition of accessing publications that users recognise and abide by the legal requirements associated with these rights.

\section{Take down policy}

If you believe that this document breaches copyright please contact us (research.lib@cbs.dk) providing details, and we will remove access to the work immediately and investigate your claim. 


\title{
The Rise and Fall of Employee Ownership in Estonia, 1987-2001 ${ }^{1}$
}

Panu Kalmi

Helsinki School of Economics, department of economics

PO Box 1210, 00101 Helsinki, Finland

email: kalmi@hkkk.fi

\begin{abstract}
This paper analyses the post-privatisation ownership dynamics in employee-owned firms in transition. We use new, detailed survey data from Estonia. We link our analysis to the long-standing literature on the viability of employee ownership. We pay attention especially to the effects from institutional environment, and to the institutional structure of the market for shares. Our empirical analysis helps us to identify the reasons behind the decline of employee ownership. The main reasons behind the sharp decline of employee ownership are: 1) excessive selection of employee ownership by uncommitted managers and employees, due to peculiarities of the privatisation process; 2) weak employee representation; 3) ill-suited property right structure that helped to undermine the viability of employee ownership.
\end{abstract}

JEL codes: J54, P31

Keywords: Privatisation, employee ownership, economic transition, Estonia

\footnotetext{
${ }^{1}$ This paper draws from several previous presentations, including a SSEES workshop in London May 2000, IAFEP conference in Trento July 2000, EBHA conference in Helsinki August 2002, EstonianFinnish workshop in Tallinn November 2002, and seminar presentations at Helsinki School of Economics and Leeds University Business School, February 2003. The author is grateful to Leonid Borodkin, Saul Estrin, Igor Filatochev, Derek Jones, Jukka Kaisla, Klaus Meyer, Tomasz Mickiewicz, Niels Mygind, Virginie Perotin, Ele Reiljan, Andrew Robinson, Kenneth Snellman, Otto Toivanen, Juuso Välimäki, and other seminar participants for useful comments. The Danish Research Council, Yrjö Jahnsson Foundation, and Marcus Wallenberg Foundation have given generous financial support for the research.
} 


\section{Introduction}

The privatisation processes in Eastern Europe created ownership structures that were much different from those observed in developed western economies. The widespread application of employee ownership in privatisation is a particularly fascinating case (Uvalic and Vaughan-Whitehead, 1997a; EBRD, 1998). The expectation of many observers was that employee ownership would prove to be temporary and a rapid convergence to more familiar ownership structures would take place (Boycko, Shleifer and Vishny, 1995; Blanchard and Aghion, 1996). Subsequent evidence has partly confirmed the transience hypothesis, since the number of employee-owned enterprises was found the decline rapidly (Estrin and Wright, 1999; Jones and Mygind, 1999a). However, relatively little is known on how and for what reasons the decline is taking place. This paper analyses these questions by using empirical data from Estonia.

Two basic approaches towards this research question can be imagined. First, one can model the transition of firms from one state (employee ownership) to another state (some other ownership structure) and use econometric methods to find out the determinants of the change (e.g. Jones and Mygind, 1999a). The second approach is more institutional, and applicable especially when one wants to explain fundamental changes in the ownership composition of firms. By using this approach, one wants to know about the details how particular ownership structures arose, whether the institutional environment supports or undermines the viability of particular ownership structure, how do the ownership changes take place at a micro-level, and perhaps to compare the outcomes under one institutional environment to those observed in other environments. ${ }^{1}$ These two approaches are certainly complementary, but in order to focus more clearly on one issue at the time, we will concentrate in this paper on the institutional side. The determinants of change at the firm-level is the subject of a companion paper.

In order to formulate an effective public policy towards employee ownership, it is crucial to understand the stability properties of this ownership form (Perotin and Robinson, 2003). Theorists of employee ownership have long worried about instability of employee ownership: if employee-owned firms tend to be unstable, then the rationale for publicly funded support for these enterprises may be questionable, especially if this support tends to benefit only a narrow group of 
employees. Supporters of employee ownership are interested in exploring the causes of instability and potential remedies (e.g. Ben-Ner, 1988).

Another issue is whether the stability of employee ownership is worth promoting in economic transition, or whether one should take measures to facilitate ownership changes towards investor ownership, as some authors have argued (Aghion and Blanchard, 1998). Even from this perspective, it is interesting to see how and to what directions ownership is changing. If privatisation policies have impact on economic performance, there are equally good reasons to suppose that subsequent ownership changes also influence performance.

Section 2 of the article reviews the relevant literature. It includes a snapshot on the discussion of merits and shortcomings of employee ownership, discusses the literature on the viability of employee ownership, and reviews the theoretical work on ownership change, as applied to transition economies. Section 3 first reviews the Estonian privatisation process, focusing on the developments that are relevant in understanding the rise of employee ownership. Then we evaluate the statistical evidence on employee ownership and its evolution in Estonia. The statistical analysis in this section mainly builds on and extends the earlier work done by Jones and Mygind (1999a) and Mygind (2000). From their work, it is already well known that employee ownership in Estonia has been in decline, and this work mainly extends the period under observation. The most original new evidence in this paper is presented in section 4 , where unique survey evidence on the institutional structure of share trade is presented. In this section, we develop an explanation for the observed patterns of ownership change. In this, a detailed micro-level data on the institutional structure of share market is instrumental. The conclusions are divided into three sections. In section 5, we attempt to generalise the findings from Estonia by outlining the conditions for the viability of employee ownership. In section 6, we return to the problems of transition by relating the findings to the proposed theoretical frameworks on ownership change. Section 7 presents the final conclusions.

\section{Employee ownership in transition economies}

\subsection{Pros and cons of employee ownership: a short literature survey}

Employee ownership has been an extremely contentious issue to economists. A voluminous literature exists on the topic. ${ }^{2}$ Employee ownership has been generally 
embraced as upholding the notions of dignity, self-management and democracy at the workplace (Dahl, 1985; Ellerman, 1990; Bowles and Gintis, 1993). Economists have traditionally used different types of arguments supporting employee ownership, referring to improved work incentives, reduced strategic bargaining at the enterprise level, or improved incentives to invest in firm-specific human capital (see e.g. Fitzroy and Kraft, 1987; Smith, 1988; Blair, 1999; Gordon, 1999). Occasionally employee ownership has been promoted by the virtue of reduced income differentials or broadened ownership of capital. ${ }^{3}$ However, for each argument for employee ownership there has been at least one counter-argument. One popular argument relates to market selection: Since worker-owned and -managed enterprises are rare, apparently this ownership form is not viable in market economies (Jensen and Meckling, 1979; Frydman and Rapaczynski, 1994). The main problems of employee ownership is limited access to finance, due to the limited wealth of the employees (Bowles and Gintis, 1993, 1996), underinvestment due to non-marketable shares (Furubotn and Pejovich, 1970) or employee risk aversion (Benelli, Loderer and Lys, 1987), or decision-making deadlocks due to the dispersed preferences of the workforce (Hansmann, 1990, 1996).

The transition economies raise an additional set of problems. Major problems for economic restructuring in these countries were the lack of capital and lack of know-how. Employee ownership was believed to lead to the continuation of old, ineffective habits of socialist times. For these reasons, many economists preferred a radical change with strong, strategic, preferably foreign owners (Aghion and Blanchard, 1998; Aghion and Carlin, 1997; Pohl et al., 1997). However, employeeowned firms, that have close ties with local community and that rather reduce wages than lay-off employee to cut the costs, were thought to have distinct benefits in situations where the local labour markets were depressed. (Earle and Estrin, 1996; Uvalic and Vaughan-Whitehead, 1997b; Mygind, 2001).

Ultimately the benefits and costs of employee ownership are empirical issues. The evidence suggests that employee ownership has a modest beneficial impact on productivity and other organisational outcomes, at least when combined with other organisational changes (Blinder, 1990; Kruse and Blasi, 1997). However, it is not clear that these results can be directly generalised to the transition environment. Even though employee ownership has become relatively common in some leading Western economies, notably in the US, employees normally own a small minority of shares, 
without significant control rights. In transition economies employees often appeared as majority or dominant owners. Moreover, in Western market economies there are no examples of economy-wide applications of employee ownership. Therefore, little can be said about the efficacy of systems where most firms are privatised to employees, as in Russia (Blasi, Kruse and Kroumova, 1997) or the Ukraine (Estrin and Rosevear, 1999). Generally, the consensus among economists (although there were a few dissenters) was that the costs of employee ownership would normally outweight its benefits in the transition context, compared to investor ownership as an alternative (Earle and Estrin, 1996).

How was it possible that employee ownership became widespread in transition economies, if it was regarded as an inferior privatisation method? The most prominent explanation in the literature of the economics of transition is based on the insider bargaining power (Boycko, Shleifer and Vishny, 1995; Aoki, 1996; Aghion and Blanchard, 1998). Since the insiders acquired during the last reform attempts of socialism de facto control rights in the enterprises, it was politically infeasible to ignore their preferences in the design of privatisation policies. The concessions given to the workforce in privatisation processes may be regarded as attempts to induce the workers to approve the reform policies, as well as means to compensate them from the forthcoming losses.

However, although this story contains important insights, it is at best a partial explanation. While it may characterise the development in certain transition economies rather well (especially Russia and Poland), it cannot explain the Estonian situation, since Estonian workers were not effectively organised in early transition. ${ }^{4}$ There is another, more general explanation for the use of employee ownership in transition. All transition economies suffered from the lack of capital in early transition. The low domestic purchasing power ruled out competitive bidding of large enterprises as a privatisation method in early transition. Since selling assets in a large scale to foreigners was not a politically feasible solution either, many economists recommended the distribution of assets to the population for free, using investment funds as intermediaries (Blanchard et al., 1991; Frydman and Rapaczynski, 1994). However, although such schemes had a partial success in the Czech and Slovak Republics, they appeared to be difficult to implement politically. As a result, the privatisation process remained in deadlock in many countries, and they were suspected to generate corporate governance problems (e.g. Nuti, 1995). In the 
meantime, privatisation to employees appeared to be a feasible solution to generate further progress in the privatisation front incrementally. Employee ownership was generated "by default" rather than "by design" (Uvalic and Vaughan-Whitehead, 1997b). This characterisation of events seems quite applicable to the Estonian case as well, to which we take a closer look below.

\subsection{Viability of employee ownership}

The problem of the instability of employee-owned firms has worried sympathetic observers of employee ownership ever since J.S. Mill. ${ }^{5}$ There are in principle two different cases of instability: First, if ownership is not extended to new employees, through labour turnover the number of employee-owners and, usually, the equity held by employees also declines. This phenomenon has been referred to in the literature as 'degeneration'. Another possibility is conversion to investor ownership, when employees sell the majority of their shares.

In the recent decades sophisticated formal models have occurred to describe the degeneration phenomenon (Ben-Ner, 1984, Miyazaki, 1984), but the point can also be made with a simple verbal explanation. Suppose that a manager of an employee-owned firm, who is for now assumed to be a loyal servant of his employeebosses, wants to hire an additional employee, and wonders whether to make this employee an owner. Suppose that being an owner does not induce the employee work any harder than he otherwise would. The cost of extending ownership is the dilution of the stakes of all existing shareholders, which must then be weighted against the financial resources the employee brings to the enterprise (as payment for his share). Additionally, the control rights and job security of existing employee-owners might get diluted as well. If the firm charges only nominal fees for sharing ownership (as sometimes is the case with co-operatives), then existing employee-owners might have strong incentives against extending ownership to new employees. Over time, when employees leave the enterprise, the number of owners gradually diminishes, until the firm has transformed into a one-man company. Another side of the coin is that if the firm is successful, incoming employees simply cannot afford to buy shares, or other problems in the market for shares (e.g. asymmetric information) prevent such markets from functioning (Dow and Putterman, 2000).

It is plausible that employees who are also owners are more productive, or that employees bring valuable capital with them, ${ }^{6}$ so degeneration is not inevitable. 
Additionally, some firms may require in their by-laws that all employees who have been employed for a certain time have to be sold shares at a fair price, or there might be restrictions on how many non-owning employees the firm can hire. Much depends on the institutional environment.

It has also been argued that especially successful employee-owned enterprises may have a tendency to convert into investor ownership (Miyazaki, 1984; Ben-Ner, 1988). It may be more lucrative for employees to sell their shares to investors rather than new employees, since the former are likely to pay higher prices for shares. However, it is not clear that only successful enterprises would be involved in such sell-outs: financial problems and need for new funding may also drive employees to sell out to investors.

The degeneration and conversion arguments have been frequently tested with empirical evidence, and the results have so far been mixed. Declines in membership and conversions to outside ownership has occurred in US Pacific plywood cooperatives (Craig and Pencavel, 1992) and in Israeli industrial co-operatives (Russell, 1995), but Israeli agricultural co-operatives or the Kibbutzim (Rosner, 1985), French SCOP co-operatives (Estrin and Jones, 1992; Perotin, 1997), and, at least until recently, Mondragon co-operatives in the Basque country (Smith, 2001) have been quite resistant against the decline. Jones (1979) finds that the US co-operatives have been in general rather long-living, but documents that some of the more successful cooperatives have sold out to investors.

There exists some studies on the changes of ownership structures in transition economies. $^{7}$ These studies indicate that employee ownership started to decline early on. However, many of these studies focus on relatively short period of time, and they do not include detailed analysis how the change takes place (with the exception of Blasi, Kroumova and Kruse, 1997, and Kozarzewski and Woodward, 2001). One important difference in explaining the ownership change in transition economies visà-vis the above cited results from developed economies is that employee ownership in transition took mainly the form of direct share ownership, while the other studies have usually discussed co-operatives.

\subsection{Should stability be promoted?}

It is another question whether the stability of employee ownership should be supported. Economists usually take the perspective that the relevant criterion should 
be economic efficiency, and we will here leave aside the perspective that employees have a compelling moral right owning the companies they work for (but see Dahl, 1985; Ellerman, 1990). Proponents of the degeneration argument have sometimes claimed that employee ownership would have efficiency advantages over investor ownership, but problems in creating marketable shares create a barrier for the success of these firms (Ben-Ner, 1988).

However, in transition literature these issues are often viewed differently. In the transition literature, there have been two particularly popular arguments. The first one can be labelled "transition device" view and the second "market selection" view. The transition device view (Aghion and Blanchard, 1998) maintains that employee ownership is technologically inefficient compared to investor ownership (in the sense that investor-owned enterprises would consume less resources to produce a fixed amount of output, compared to their employee-owned counterparts). However, employee ownership is useful in separating the firm from the state control. The normative prescription emanating from this view is that any obstacles on the transition to more conventional ownership structures should be removed. Especially, infirm registration of shares should be avoided, share trading should be anonymous, and ESOP-like structures should be avoided (Aghion and Blanchard, 1998, p. 96).

The market selection view does not require defining the efficient structures ex ante. This view recognises that the initial ownership structures are more likely to reflect outcomes of political bargaining and therefore they are not likely to be optimal from an economic standpoint. However, market forces compel firms to adjust ownership structures, since inefficient structures become too costly to maintain (Demsetz and Lehn, 1985; Hansmann, 1996). It is not necessary to define the optimal ownership structures in advance, but the market forces performing the selection. The normative prescriptions of this approach are very similar to the transition device approach: Ownership structures should be as flexible as possible, in order to minimise the adjustment costs to optimal ownership structures (Earle and Estrin, 1996). When ownership structures can be expected to change later on, the importance of initial ownership allocation declines in importance, and one can implement the privatisation strategy that is politically feasible, not the one that is economically most efficient (Boycko, Shleifer and Vishny, 1995).

Both of these perspectives focus on technological efficiency. An alternative view would rely on the preferences of the workforce: An ownership change is 
efficient, if it is in the interest of the majority of the workforce. Mygind (1992) calls this type of efficiency as internal efficiency. But if employees own the majority of shares, how can ownership change take place against their preferences? First, if employees do not own the firm fully and shares are individually tradable, then it is possible that outside investors need to persuade only part of the employees to sell their shares in order to gain the control. Second, employees may not take into account the value of the control rights and sell individually their shares when it would be collectively in their interest to hold on to their shares (Blanchard and Aghion, 1996). Third, managers can sometimes dilute employee holdings by issuing new shares, and thereby changing the ownership structure. Fourth, managers can also sometimes use coercion in order to induce employees to sell their shares, for instance by threatening to dismiss employees. Although employees could in principle respond to such threats by using their majority position in the shareholder meeting and oust the management, in practice the coordination problems in the absence of effective employee organisations may prevent this.

Finally, there is the problem how the preferences of the workforce should be aggregated. Under individual share ownership, the preferences are weighted according to the number of shares owned. However, it is not clear that such weighting leads to efficient outcomes. Kalmi (2002a) shows that efficient ownership changes require that employees own the shares collectively (which can be modelled according to US ESOPs) and the decision-making of the trust is allocated according to one man, one vote -basis. Such a scheme would not rule out outsider involvement (most US ESOPs combine investor ownership with employee ownership), but it would strengthen the bargaining power of employees in ownership processes. Contrary to the argument of Aghion and Blanchard (1998), such an arrangement does not need to prevent efficiency-enhancing ownership changes; on the contrary, it can be argued that it makes such changes more likely, since employees can share from in the appreciation of share price (Lazear and Freeman, 1997; Brown, 1998).

\section{Privatisation and ownership changes in Estonia}

\subsection{Privatisation process and initial ownership structures}

In this section, we will concentrate on privatisation processes that were important for the rise of employee ownership in Estonia, leaving aside other important 
developments in privatisation. We also exclude the smallest firms (less than 10 employees) from the analysis, and therefore do not discuss small privatisation. ${ }^{8}$

The roots of employee ownership in Estonia are in the last reform attempt of the Soviet Union, known as perestroika. When the inefficiencies of economic planning and state control became ever more apparent by the mid-1980s, the first secretary of the communist party of the USSR, Mikhail Gorbachev, decided to allow the formation of privately-owned enterprises. Between 1987-1990, several hundreds of small state enterprises and worker co-operatives were established in Estonia. In relation to the size of the economy (Estonia had less than 2 million inhabitants), the density of these small private enterprises was in Estonia one of the highest among the socialist republics of USSR. The workforce in small state enterprises and cooperatives gained the right to decide on production, pricing, wage setting, and investment (although in the limits imposed by state authorities), and, importantly, they obtained the right to keep the net revenues. However, it became soon apparent that these measures were insufficient to revive the economy. In 1989 started semiprivatisation of large industrial enterprises, known as leasing of state enterprises. The leaseholders gained the right to control the enterprise and the right to residual revenues. In essence, they were private firms, lacking only the third important element of ownership, namely the right to transfer the assets to third parties. They also had to pay rent for the use of assets to the government.

By the end of 1980s, the Estonian government started to resist openly the control from Moscow and initiated own reform programmes. One important document in this was the proposal of economic self-management, known by its Estonian acronym IME, already from 1987 (Terk, 2000, p. 23). However, in privatisation policies the Estonian initiatives followed quite closely those imposed from Moscow. The two most important initiatives increasing employee ownership in Estonia were the Estonian variant of leasing that started in 1990, and the privatisation of collective farms that started in 1992. (Estonia became fully independent in 1991.) Since the centralised privatisation programme of large enterprises started only in 1993, leasing was for the time being one of the few options for the state firms to separate themselves from the state control. The lease contract necessitated that a significant proportion of employees became co-owners. Unlike in the Polish and Russian variants of leasing, the leaseholders did not have the pre-emptive right to buy the assets when the lease contract expired. However, it was extremely rare that 
someone else than the leaseholder (i.e., employees collectively) bought the property. Some 300 units were privatised in this way (Terk, 1996). Somewhat related (but quantitatively much less important) programmes were the transformation into so called "people's enterprises" and experimental privatisation.

The privatisation of collective farms to their employees was based on the principle that the property belonged to the employee collective and not to the state. A similar principle was also used in the privatisation of state farms, although the state was a nominal owner of these farms. The employees were granted "labour shares" according to the length of their service in the collective farm, which they could invest in the enterprise assets. The collective and state farms consisted of several units, most of which were auxiliary to agricultural production (e.g. small manufacturing, electricity works, construction etc.) Although there were only around 340 collective and state farms in 1989, it has been estimated that over 3000 successor enterprises existed in 1995, of which majority were employee-owned (OECD, 1996). Of these enterprises, less than 1000 were involved in agriculture and the rest in other industries. These figures do not include the large number of firms from the collective sector outside collective farms, that sprung off from the consumer co-operative movement, construction associations, and machinery associations.

The privatisation policies in Estonia changed notably following the establishment of Estonian Privatisation Enterprise (EPE) in September 1992, new law on privatisation in summer 1993, and the establishment of Estonian privatisation agency (EPA, follower of EPE) in autumn 1993. From late 1992, the majority of enterprises have been sold in a tender to strategic investors. The winner of privatisation contest was decided on the basis of the price offered for the shares and on the development prospects the new owner could offer for the enterprise. Privatisation has included the use of vouchers since summer 1994. After the change in privatisation policy and especially since 1994, it became very rare that the enterprises were privatised to employees. The new privatisation policies removed any preferential treatment of employees in the privatisation process, and the stress on core investors actually put employees to a disadvantage, compared to other groups.

Table 1 describes the allocation of ownership immediately following the privatisation. We use data collected by the Estonian Statistical Office and Center for East European Studies, Copenhagen Business School. This data has already been used for a number of studies, including Jones and Mygind (1999a; 1999b; 2000; 2002). 
The initial sample included 500 Estonian firms that were private (new or privatised) in 1995. The sample was drawn from the list of enterprises at the Estonian Statistical Office. It is representative and includes all Estonian regions and industries. ${ }^{9}$ The sample is stratified by the size and industry. Of the 500 firms that belonged to the sample, 409 (82\%) responded to the survey. From these, we exclude firms with less than 10 employees in 1995, leaving a sample of 364 firms that were private in 1995 , i.e. they were privatised or established de novo at some point between 1989-1995.

\section{TABLE 1 AROUND HERE}

The firms are divided into four distinct groups, according to which is the largest group of owners: Non-managerial employees, managers, domestic investors, or foreign investors. The origin of the enterprises are likewise divided into four groups: former state-owned enterprises, former collective enterprises (including not only collective farms but also firms that are successors to the consumer co-operative movement, construction associations, and agricultural machinery associations), former joint ventures, and new firms. From this table, it appears that the outcome of privatisation is clearly dependent on the history of the firm. While privatised state firms fall into all categories, more of them were privatised to employees than to any other group. Most of these firms followed the leasing procedures. Firms from the former collective sector went into domestic investors (which often are former central co-operatives), or to employees. ${ }^{10}$ Joint ventures were typically purchased by the foreign investors. New firms are established by foreigners or managers, while the proportion of employee-owned firms among these firms is surprisingly high. ${ }^{11}$

The intriguing question is, why did employee ownership in Estonia become widespread, even though there were no serious political parties supporting it (Terk, 1996)? While Estonia was still part of Soviet Union, the only way to separate the firm from state control was to transfer the ownership to employees. Until around 1990, the Estonian privatisation policies closely followed those established in the Soviet Union. At this time, privatisations involving employees were the only option. The national privatisation policies started in 1990. However, privatisation remained the bedrock of party disputes well after regaining independence in 1991, up to 1993. It would have been impossible that nothing had happened in the privatisation front in the meantime. Especially when Estonia was still part of Soviet Union, it was important to create a constituency that benefited from economic reforms, thereby to guarantee the irreversibility of reforms (Roland, 2002). This led into the use of employee ownership 
in the privatisation of state firms. The reason for privatising collective firms to employees was somewhat different, since employees were considered having a legitimate stake in these firms, due to their pseudo-cooperative ownership structure. ${ }^{12}$

\subsection{Ownership changes}

In this section the ownership changes in Estonian firms are evaluated. This analysis extends the previous analyses in Jones and Mygind (1999a; 1999b) and Mygind (2000) that evaluated the ownership changes up to 1998-1999, using the same data (although slightly different definitions). Table 2 presents the ownership changes between privatisation and the beginning of the year 2001. The first thing to notice is that the sample of 364 firms shrinks considerably before 2001. 135 enterprises or 37 $\%$ of the sample firms exit from the sample. This includes exits because of liquidation, but more commonly this reflects sample attrition: the respondent simply does not answer to the survey any longer. Because we cannot reliably distinguish liquidation of the firm from simple refusals to participate in the survey, we will ignore this distinction in later analysis.

\section{TABLE 2 AROUND HERE}

The ownership structures are the same as in the table 1, except for one new category in 2001: Firms that have moved into the ownership of their former employees. Because ownership is not directly linked to employment, employeeowners who leave the firm cannot be requested to sell their shares when they leave the firm. If the shares are not bought back from employees upon departure, ownership accumulates gradually outside the enterprise, in some cases leading former employees to become the dominant owners.

Rows indicate the ownership structures at privatisation and columns ownership in 2001. The decline of employee ownership is apparent. While employees initially control 47 enterprises (21\%), by 2001 the number has declined into 12 (7\%). Note also that while employee-owned firms move massively into other ownership structures, there are only a few (4) firms changing into employee ownership during the period. Another group that has declined in number is firms owned by domestic investors, but the decline has been much more modest (from 67 to 59 firms). ${ }^{13}$ Foreign-owned firms are very stable, while the increase has occurred to manageriallyowned firms (from 55 to 79) and to firms owned by former employees (from 0 to 17). Another interesting phenomenon in the table is that if we classify the firms owned by 
employees, managers, and former employees as "insider-owned", and firms owned by foreign or domestic investors as "outsider-owned", then, surprisingly, insider ownership has increased in Estonia during the economic transition. Given that many economists have made strong claims on the superiority of outsider ownership, this result is contrary to the expectations.

In table 3 we investigate the decline in employee ownership closer, by taking a look at the decline year-by-year. By the end of 1994, 21 of the 72 firms had moved into other ownership structures, mainly to the ownership by managers, former employees, or domestic investors. Throughout the whole period, it was rather rare that an employee-owned firm moved into foreign ownership. A big change occurred in 1996, when 18 firms moved into other ownership structures. Most of these went into managerial ownership or the ownership of former employees. After this point, the decline becomes more gradual, while by the end of the period it almost ceases altogether. It is not entirely clear why the decline first accelerates in 1996 (a period of rapid growth) and why the rate of decline subsequently starts to decrease, nor is it clear why managerial ownership in these enterprises suddenly falls in 1999. In any case, the numbers indicate a substantial decline in employee ownership.

\section{TABLE 3 AROUND HERE}

What kind of firms initially adopted employee ownership, and what kind of firms change from employee ownership to other structures? The traditional picture of employee-owned firms is that they engage in petty manufacturing, services or construction, and that they are smaller and less capital-intensive than firms with more conventional ownership structures (e.g. Hansmann, 1996). The previous analyses of Mygind (2000) and Kalmi (2002a) show some interesting patterns concerning the Estonian sample. One surprising character in Estonian employee-owned firms was that in 1994, median employment in employee-owned firms was 95 employees, more than twice the employment in other firms. A plausible explanation for this finding is that employee-owned firms were less often new firms, that are generally smaller. On the other hand, employee-owned firms were less capital-intensive and especially they had smaller equity capital per employee: The median nominal share capital per employee was only 1600 EEK (around 100 EUR), while it was over 7000 EEK (around 450 EUR) in other firms. Moreover, similar low capital / employee ratios extend to manager-owned firms, meaning that the nominal capital per employee were much higher in firms owned by outside investors (Mygind, 2000; Kalmi, 2002a). 
Since nominal capital usually reflects the privatisation price of privatised firms, this finding suggests that insiders could buy assets much more cheaply than outsiders in the privatisation process. There were no clear industry patterns in the initial allocation of employee-owned firms, but they were represented in all industries. Employeeowned firms were somewhat more profitable than other firms, but labour productivity (value added per employee) was slightly lower. Employee-owned firms were more often located in countryside than other firms.

By the end of 1999, many things had changed. Employment was at the same level in employee-owned firms as in other firms, reflecting both the fact that many large employee-owned firms changed into outsider ownership, and that employeeowned firms tended to decrease employment much more than other, especially foreign-owned, firms. Almost all employee-owned firms that were established in towns or that were new had changed ownership. In fact, mainly those enterprises that were established as the successors of the former collective farms remain as employeeowned. This probably suggests that there is no outside demand for these firms. Employee ownership is also motivated by the desire to save jobs and retain the social stability in rural communities, that are often quite dependent on the single employers. The remarkable difference in nominal capital per employee remained: In the end of 1999 the median was around 4000 EEK (250 EUR) in employee-owned enterprises and over 18000 EUR (1 125 EUR) in other enterprises. 4000 EEK corresponds roughly to monthly median salary in Estonia during that time.

\section{Survey evidence on ownership changes}

\subsection{Direction of ownership change: some conceptual issues}

In this section, we discuss how ownership is expected to develop in employeeowned organisations, and how ownership change takes place in practice (through sale of existing shares, through share issues, or through attrition). While the first issue has generated substantial controversy, the latter issue has been largely ignored in the literature. After this discussion, we develop some hypothesis for the empirical part, which are then tested with survey data from Estonia.

Along the lines of the market selection hypothesis, one could expect that ownership changes would follow efficiency advantages. If outsider-owned firms are really more efficient than insider-owned firms (Aghion and Carlin, 1997; Aghion and Blanchard, 1998), there are two reasons why we should expect to see changes from 
insider to outsider ownership. First, if the ownership change is efficiency-improving, then in principle there should be a way to divide the gains so that everyone is better off after the change, so no-one should object the change. Second, if insider-owned firms are less efficient, they cannot survive in the competition with outsider-owned firms, and in order to survive have to sell control to outsider investors.

Similar considerations can be extended to other forms of ownership changes. For instance, management ownership can be more efficient than employee ownership, because of lower decision-making costs and greater entrepreneurship by managers (Earle and Estrin, 1996). The strength of employee ownership is improved work motivation and enhanced incentives to invest in human capital. For these reasons, employee ownership can be regarded as superior to ownership by former employees. Substantial ownership by former employees does not enhance the work motivation of incumbent employees. Moreover, former employees are typically small and dispersed owners, with weak incentives to monitor management. In sum, purely by efficiency grounds we would expect most changes to outsider ownership, then changes to managerial ownership, but not changes to the ownership of former employees.

Some of the early theoretical analysis predicted that employees would be inclined to sell their shares to outsiders even in the absence of gains in productive efficiency (Blanchard and Aghion, 1996; Chilosi, 1996; OECD, 1996; Aghion and Blanchard, 1998). ${ }^{14}$ This reasoning was based upon the following assumptions: 1) employees are risk averse and would prefer to invest their money in less risky ways; 2) employees value current consumption and therefore would like to sell their shares to more patient investors; and 3) employees would not take into account the impact of their shareholding to their employment security and, mistakenly, would sell their shares to outsider investors even in the case when they would be better off by not selling their shares. Moreover, the underdevelopment of capital markets amplifies the problems arising from risk aversion, impatience, and wealth constraints (Mygind, 2001). These arguments would thus lead us to expect an even faster decline of employee ownership than pure efficiency considerations would lead us to expect.

On the other hand, some previous literature would caution against making too strong assumptions on the nature of market for shares in employee-owned firms (Dow and Putterman, 2000). These imperfections may prevent especially new, incoming employees from becoming owners. New employees may be younger and therefore more risk averse and wealth constrained than incumbent employees, which makes it 
difficult to find a mutually agreeable price for shares. They may also fear that more experienced employees try to take advantage of them and sell them overvalued shares. Due to limited number of participants, share trading is infrequent and prices often do not convey relevant information about the real value of the shares. Incumbent employees may also fear that new employees will change the decision-making balance.

The issues of imperfect information hinder also ownership markets regarding the trading between insiders and outsiders. For instance, asymmetric information regarding asset quality may also prevent potentially efficiency-improving transactions. Insiders may also refrain selling their shares to outsiders, since they may fear major lay-offs once investors take over control. Investors may have difficulties in credibly committing to honour the rents insiders currently enjoy (Shleifer and Summers, 1988).

These inherent difficulties make the operations of the market for shares in employee-owned firm difficult, but as shown above, risk averse and impatient employees may also be too willing to sell their shares to others. To prevent this from taking place, insiders may deliberately impose constraints on the tradability of shares. They can do this formally, for instance by imposing by-laws that say that shares can be traded only among current shareholders, or informally, e.g. managers by threatening to dismiss workers who sell outside the firm or employees ensuring compliance by peer pressure. However, in Estonia by-laws limiting the potential shareholders are perfectly legal, so almost all non-publicly traded firms restrict the group of potential shareholders by these by-laws. These restrictions are usually designed to prevent unwanted outsider take-overs, but few firms prevent employees selling their shares to enterprise managers.

While formal constraints on the tradability of shares might be sufficient to exclude outsider investors, the regulation of ownership between insiders might take more subtle forms. Management typically controls the ownership processes. The privatisation process was almost always initiated by the managers. They also initiate new share issues, and conduct negotiations with potential outside investors (Kalmi, 2002a; Kalmi and Mygind, 2003). They can obviously use this control to their own advantage. Management is likely to have more correct information about the value of shares, and can use this in transactions with employees. Importantly, they also control the possibilities for participation in decision-making at different levels and 
information on firm performance. Both participation and information flows significantly affect employees' valuation of their shares. By withdrawing participation possibilities, information on performance, and dividends, management can convince employees that their shares are worthless, and buy them at undervalued prices. Again, our analysis implicitly assumes that employees are not capable of detecting the management behaviour and removing the management by the virtue of their shareholding. It may be argued that in such cases employees are not capable of being "real owners", and changes to management ownership can only improve efficiency. ${ }^{15}$ While there is some truth in this claim, we would like to point out that this is an example of "endogenous preferences" (Bowles, 1999), where the preferences of the employees towards ownership depend on the behaviour of the management. In this situation, the efficiency of control transaction become context-specific. Employee ownership could be more efficient under a more participatory management style.

To summarise the discussion so far, we would expect to see many other influences than pure efficiency advantages in the market of ownership. While employees may be willing to sell their shares due to risk aversion and impatience, they also worry that selling shares may signal low commitment to the enterprise (Kalmi, 2000) or they fear that selling shares exposes them to social sanctions of fellow workers, and they therefore refrain from selling shares. However, retired (or former) employees are outside the social control of the workplace and they are more willing to sell their shares. The problems of share market, related to risk aversion, information problems, and limited number of participants, tend to depress the price for shares. In such a situation, everyone, including former employees, prefers to hold on to their shares, and wait for better prices.

For reasons of rent protection, it is especially important for insiders to prevent outsiders from buying undervalued shares. This is likely to take place via formal constraints designed to prevent outsider participation. Incoming employees are in a similar situation than outsider owners, i.e. they may neither be entitled to buy shares. Because of their risk aversion and wealth constraints, they are actually even more unlikely to buy shares from incumbent insiders, even if given the opportunity to do so. However, if the management values regards employee ownership as a valuable goal in itself and wants to extend ownership also to new employees, the obstacles may be overcome. On the other hand, it is more likely that managers use their control of 
ownership processes and information to improve their own position. We would then expect as a result:

- former employees being most likely group to sell their shares;

- concentration of ownership to managers;

- exclusion of new employees;

- limited participation of outsiders;

- formal constraints against outsider participation;

- trading of shares to be infrequent;

- trading of shares to take place at undervalued prices.

\subsection{How does ownership change take place: the role of new share issues and attrition}

Ownership can change also by other means than trading existing shares. An alternative possibility is to change ownership structures by issuing new shares. There are a number of differences between these two approaches. First of all, employees may refrain from selling their shares, because such an act would signal low commitment to the enterprise and possible quit intentions. Non-participation in share issues would not be interpreted in this way.

Second, in some cases issuing new shares can be a cost-efficient way to gain control. In Estonia, employees have usually bought shares at their nominal values. They are usually not interested in selling their shares unless they receive a premium to be paid on the top of their shares. However, new shares may be traded at their nominal values. This means that managers can possibly increase their shareholding in a less expensive way by issuing new shares. Even if employees value the shares above their nominal value, they may not participate in new share issue, either because of wealth constraints, or because managers compel them to do so, either by withholding information or threatening by sanctions. Case study evidence from Estonia (Kalmi and Mygind, 2003) strongly suggests that new share issues are usually initiated by the managers in order to increase either their holdings or to invite a friendly outsider. Since usually only managers are in position to initiate new share issues, this creates a strong bias towards increased managerial ownership. ${ }^{16}$ In situations where the nominal value of shares is very low compared their real value and where managers 
can effectively exclude employees from buying new shares, share emissions provide attractive means for managers to increase their shareholdings.

New share issues are also a way to generate new equity funding. Managers can possibly take over the firm in a less transparent way if they do it by new share issues, since they can frame it as injection of equity finance. This has been relevant especially in early transition, when employees were not very much educated about their rights as owners.

Another source of ownership change that is often ignored in the literature is attrition. This means that when the initial cohort of employee owners gradually retires, they do not pass on their shares to the incoming new employees, but rather keep their shares. In this way, the ownership shifts gradually outside the enterprise. Alternatively, retired employees may sell their shares only to those employees who belong to the initial cohort of owners. In this case, the majority of shares may in the medium-term remain in the enterprise, but ownership becomes more concentrated. In the long run, also this contributes to the demise of employee ownership. The only way to prevent the "degeneration" of employee-owned organisations into outsider-owned enterprises is to generate a mechanism to transfer the shares to incoming insiders.

The hypothesis emanating from this section are:

- New share issues may be more important in inducing ownership change than trading existing shares;

- Attrition leads into increased ownership by former employees and / or into concentration of ownership among incumbent employees, leading to further decline in employee ownership.

\subsection{Survey evidence}

To investigate these issues empirically, we conducted in co-operation with the Estonian statistical office a survey during the spring 1999. The surveyed firms had at least $20 \%$ of their shares owned by employees in 1995. The respondents were drawn from the larger, representative sample described above. This survey included questions about share trading and ownership change during the period beginning of 1996- spring 1999. The initial sample included 99 firms, and 74 firms responded. 37 of these were former state-owned firms, 17 successors of collective farms, 18 new 
firms (most of them being manager-controlled), and 1 former joint venture (one respondent did not indicate its origin). There were no publicly traded companies or co-operatives in the sample. The ownership changes in this sample of course reflect the patterns found in the large sample: In 26 of the 74 firms employees were the dominant owners in 1995, but they remain dominant owners only in 9 enterprises in 1999. In contrast, among the other 48 firms only 5 had changed the dominant owner during the three-year period. Of the 26 initially employee-owned firms, 6 had shifted into managerial ownership, 6 into outsider ownership, and 5 into the ownership of former employees. In this article, we limit the analysis only to the 26 companies with dominant employee owners in the beginning of 1996. Let us now examine how the ownership changed in these companies.

Regarding the trading of shares, in 10 of the 26 companies there was no trading of existing shares during the period 1996-1999. In 7 more companies, only little trading occurred (less than $10 \%$ of existing stock was traded). Still, 8 of these 17 companies changed owners, so something else must explain their ownership change. Of the remaining 9 companies, substantial trading of shares took place. In all of these ownership change took place, so share trading clearly is connected with ownership changes. The three year mean of share trading is $16.5 \%$ of the existing stock, or 5.5 $\%$ annually. ${ }^{17}$

The main direction of trade is from former employees to managers (Table 4). In 11 out of 16 cases, former employees have been selling their shares, while managers have been buying shares in 11 cases. Incumbent employees are both selling and buying shares (selling in 8 cases and buying as well in 8 cases), but they are selling less frequently than former employees and buying less frequently than managers. Outsiders are buying shares only occasionally (in 3 cases of the 16). Practically all firms apply the right of first refusal, meaning that shares can be sold outside the initial group of shareholders only if incumbent shareholders agree. Sometimes the approval of management board needs also be obtained. The trading of shares serves rather to concentrate shareholding among the initial group of owners rather than to include outsiders.

\section{TABLE 4 AROUND HERE}

Of the ten cases where the respondents revealed the average price for shares, in five it was higher than the nominal value and in other five it was equal to the nominal value. Kalmi (2002a) has shown that for the Estonian firms nominal value is 
mostly a gross undervaluation of the firm value. ${ }^{18}$ Low frequency of trading together with undervalued nominal prices indicates that the prices for shares are often not responsive to supply and demand. Hence, it is questionable whether we can say that a market for shares exists.

New share issues are another possibility to change ownership structures. ${ }^{19}$ It appears that in sample firms new share issues were slightly less common that trading of shares (12 firms did not issue new shares during the period, while 14 did), but if shares are issued, the impact to the ownership is potentially larger (mean of new shares to all shares was $23.1 \%$ ). Mostly managers were buying the new shares (table 4). New shares are in all cases issued at nominal values, which gives support to the contention that it might be cheaper for managers to increase their holding by new share issues rather than by buying existing shares. It is notable that employees participate quite infrequently in new share issues.

The are four cases where employees lost their control position, even though there were no new share issues and no or insignificant trading of shares. In these cases, the loss was due to attrition. The number of employee-owners has declined in 21 of the 26 companies, including four companies where employees have remained as dominant owners, and in all other companies. In four of the companies where employees had remained dominant owners, the number of employee owners had remained more or less stable, and in one there had been a clear increase. At least some of these companies must have sold shares to new employees. However, only one respondent indicated that his firm had a deliberate policy of including new employees as owners.

Table 5 cross-tabulates the direction of ownership change and the reason for ownership change. Since often all three influences work simultaneously, the assignment of cases is sometimes difficult, and the table should be taken as indicative, rather than exact. However, it appears that new share issues have been at least as common reason for ownership change than trading of shares. Both managers and outsider owners have taken over companies by new share issues. Attrition, in turn, has changed ownership structures in companies where there has been little or no trading of shares. Usually this had led former employees to be the dominant owners, but in one case this has led managers to become dominant owners and in one case outsiders. In these cases, the ownership stakes of managers and outsiders, respectively, have remained stable, while the initial employee dominance has withered when the 
employee-owners have retired. This increase in the ownership of former employees were not in these two latter cases not sufficient to make them into dominant owners. Only 5 companies out of 26 reportedly did not have former employees among owners.

\section{TABLE 5 AROUND HERE}

In some sense, attrition is even more fundamental problem for the stability of employee ownership than Table 5 would indicate. The process leads to decreases in the ratio of employee-owners to owners, further concentration of ownership and / or gradual shift of ownership outside the enterprise. As a result, owners have now stronger interest as capital owners than employees. Moreover, incumbent employees may become disinterested towards employee ownership, because the firm is gradually losing its employee-owned character. Both of these factors increase the likelihood that the remaining shares will be sold to outsiders or managers, and decrease the likelihood that the insiders would attempt to revitalise employee ownership by selling shares to new employees. Attrition obviously undermines the long-run viability of employee ownership. The question, why Estonian employee-owned firms do not have incentives to enlarge ownership, is discussed in section 5.

\subsection{Conclusions from survey evidence}

The survey evidence gives support to the hypotheses presented above. Former employees sell shares because they can no longer gain employment-related rents from the firm. Instead, they may be subject to moral hazard by the incumbent insiders, who might be tempted to raise wages at the expense of dividends, once a substantial portion of shares is in the hands of former employees. However, former employees have also become major owners in many of the firms. This probably reflects either the wealth constraints of incumbent insiders, or alternatively their insufficient interest in investing in these firms. Infrequent trading of shares also explains why former employees have become owners. In more than one third of the sample firms, there was no trading of shares in the three-year period under observation.

Managers increase their ownership by buying shares especially from departing employees and from issues of new shares. Managerial ownership is growing fast in these firms. The reason for this is likely to be the informational and hierarchical advantages possessed by the management. Managers can decide to issue new shares when it suits them best. It might also be difficult for the employees to oppose this development, since managers have the power to sanction nonconforming employees. 
Almost all firms limit their trading to current owners, thus excluding new employees or outsiders. Ownership by outsiders and new employees must be accepted by the shareholders, board of directors or managers. When there is share trading, shares are typically traded at the nominal value or close to it, which in most cases is a substantial undervaluation of the shares. Because of low prices, the trading of shares remains infrequent.

We find that share issues are an important reason for ownership change. The proportion of new shares issued, relative to the existing shares, is often much larger than the proportion of existing shares that is traded, so their potential to shake ownership relations is also larger. Attrition seems also to be an almost universal cause of the decline of employee ownership. Only one survey firm maintained the practice of including new employees as owners. Contrary to the commonly-held view, share trading seems to be no more important reason for the decline of employee ownership than share issues or attrition.

Although these findings from the smaller survey are consistent with the findings from the from the larger sample, we believe that we have managed to uncover issues that are not tractable without microdata on ownership changes, such as presented in this paper. We find that the decrease of employee ownership often does not take place because employees would rush to sell out their shares, but because they fail to participate in new shares issues and especially because of attrition and failure to include new employees as owners. ${ }^{20}$ Furthermore, we find that limited outsider participation is often due not only to asymmetric information and lack of interest, but also because of explicit obstacles employees make. Concerning former employees, we paradoxically find that their ownership is growing but they are also more likely to sell their shares. Therefore, many enterprises are likely at some point to have former employees as the largest group of owners, but it is likely to be only a transient state. Finally, we suspect that managers often benefit from the lack of ownership market, since this enables them to substitute the price mechaniams with their authority. Managers are in an excellent position to increase their ownership in employee-owned firms, if they only want to use this option.

At this stage, we are unwilling and incapable to make statements on the efficiency and economic impact of ownership changes. This would require a larger data set. This is an issue for further research. 
What about companies that remained in employee ownership? Characteristic for them was the absence (or near absence) of share trading and stability in the number of employee owners. In other words, these enterprises seem to suppress markets for shares, in order to prevent the concentration of shares, but allow for limited trading in order to include new employees as owners. These forms share thus the characteristics of co-operatives. Employee ownership in these companies has the potential of being long-lasting. On the other hand, it is clear that these companies are a clear minority among the Estonian employee-owned firms.

\section{Conditions for the stability of employee ownership}

Why did the number of employee-owned firm first decline rapidly, and later on the decline halted? Does the Estonian experience indicate that employee ownership is not viable? Could anything have been done to prevent the decline from happening? The immediate answer to these questions is that employees sold their shares, did not object the dilution of their ownership stake, and especially did not extend ownership to new employees, because there were no or few benefits from employee ownership. The econometric evidence shows that employee ownership does not have productivity advantage over alternative ownership forms (Jones and Mygind, 2002). Case studies further show that is does neither improve job attitudes (Kalmi, 2002b) nor promote restructuring (Kalmi and Mygind, 2003). The fact that employee ownership did not cause as poor results as sometimes expected can hardly provide a rationale for sustaining employee ownership.

But this immediately leads to a broader question: why did employee ownership fail to have a positive effect on firm performance in Estonia, which it apparently has on firms in Western economies? In our view, the answer lies partly in the process how employee ownership came into being. A recurring theme in the literature is that employee ownership is selected less often than would be optimal, for instance because of employees' limited wealth (e.g. Bowles and Gintis, 1996). However, due to these difficulties, the insiders who actually select employee ownership, are likely to be exceptionally motivated, which may explain the positive results. However, once employee ownership became favoured in the selection process - due to the exceptional circumstances of the early transition - suddenly there might have been an excessive selection of employee ownership. For instance, in Estonia, many firms had in the early privatisation process two options: to privatise to 
the entire workforce, or to remain in state ownership. (Actually there was a third option as well, namely liquidation). Broader selection would have certainly led to smaller but perhaps more stable employee-owned sector. Now many managers saw employee ownership mainly as a transitional device from state control to management control. ${ }^{21}$

Second issue concerns employee representation. According to the literature on employee ownership, information sharing and participation enhance the effectiveness of incentives derived from share ownership (Kruse and Blasi, 1997). If this is correct, then the absence of employee participation reduces the potential positive impact of employee ownership, and lowers the value of shares. Absence of participation may also have direct influence on employee preferences: managers can convince employees that their shares are not worth anything, and buy the control at discount. Even if the ownership change has superficially taken place according to employee preferences, the low utility employees assigned to the shares was in large part due to management influence.

Well-functioning and stable employee participation schemes does require developed employee representation. This is not the case in Estonia, where employee representation in firms was during the 1990s at a very low level (and still is), both regarding ownership related issues or general decisions. The old trade union representatives became disreputed after the fall of Soviet rule, and the successor unions have remained weak.

Third issue concerns the property right structure. Employee ownership in Estonia took the form of direct shareholding, where employees are free to sell their share at will, and where ownership is based on invested capital rather than labour input. Such a system is much more vulnerable to instability, due to employees selling their shares, concentration of equity, and no inbuild mechanims for including new employees. Only the underdevelopment of (or lack of) markets for shares has slowed down the decline in ownership. Approaches based on indirect ownership (such as the US ESOPs) would have lead to more stable ownership patterns.

As we noted above, earlier empirical studies on the issue of "degeneration" have not found such rapid declines in employee ownership as the process has been in Estonia. However, these studies have usually discussed only co-operatives. Cooperatives, in turn, satisfy all three conditions mentioned above: They have typically highly motivated workforce who are committed to co-operative values; they have 
highly developed employee representation (based on one man, one vote -principle); and they have the entitlement of ownership based on labour input, not on invested capital. The Estonian experience does not indicate that employee ownership is bound to fail everywhere, but it suggests which individual features are necessary for stability, and why there has been so much stability among co-operatives.

\section{Employee ownership and transition strategies}

Which explanations of ownership change - the degeneration, market selection, or transition device view - are supported by empirical evidence? The market selection view and the degeneration view generate somewhat different predictions concerning the ownership change. The market selection view would predict that those firms that are not well suited for employee would change to other ownership structures, while in the end there would remain a core of firms for which employee ownership is suitable. This view would predict a declining rate of ownership change. Degeneration view based on attrition would, in turn, predict an increasing rate of ownership change over time, since over time more and more employees would retire and further ownership concentration would give increased incentives for remaining employees to sell out (Kalmi, 2002a). The overall pattern of ownership change seems to support market selection view more than degeneration view on this account: The statistical evidence shows first a rapid decline of employee ownership, and then stabilisation at relatively low level of ownership.

Transition device argument has two different sides: Either employees do not collude and sell their shares quickly, or they collude and ownership structures stagnate. At the first glance, the data does not seem to support either of the arguments. Because of the absence of the market for shares, employees simply cannot sell their shares to outsider interest quickly; on the other hand, evident collusion has not completely stagnated ownership structures, since employee ownership has declined rapidly. However, Aghion and Blanchard (1998) are mainly interested in the dichotomy of insider vs. outsider ownership and less on the composition of internal ownership. Since insider ownership has been very stable relative to outsider ownership, Estonian experience can be interpreted to support their collusive model.

The market selection view can be criticised from making too strong assumptions on the workings of the market. The research has shown that ownership changes are not always based on price but sometimes also on command and coercion. 
Sometimes ownership shifts to groups that hardly are most efficient owners: former employees are a case in point. However, it is possible that in other cases ownership changes are efficiency-improving. More research needs to be done on this point. At this point, it is interesting to notice that the research from Estonia (Jones and Mygind, 2000; 2002) as well as from elsewhere in transition (Djankov and Murrell, 2002) have shown foreign ownership to bring most results, but changes from employee ownership to foreign ownership are virtually non-existent. Changes to managerial ownership can sometimes bring efficiency improvements, but sometimes be motivated by managerial authority and bring meagre results. Case studies on Estonia (Kalmi and Mygind, 2003) present examples of both cases.

The attrition phenomenon supports the degeneration view. In many firms, employee ownership is declining because it has not been possible to introduce markets for shares. On the other hand, there is a minority of firms that seem to get around this problem. This indicates that the decline in employee ownership is not a unitary phenomenon. Instead, different reasons for the decline exists, some of which might be conducive to efficiency and some not.

\section{Final conclusions}

We have contributed to the literature on ownership structures in transition economies in several ways. We have focused on the decline of employee ownership in transition, using empirical evidence from Estonia. We linked longstanding literature on the viability of employee ownership to the questions of transition. We also discussed two alternative frameworks, the transition device approach and the market selection approach, that have been more dominant in the transition literature.

However, our main contributions were empirical. We showed that employee ownership has declined substantially in Estonia during the economic transition, although the decline halted in late 1990s. We also showed that most of this decline has been changes to other forms of insider ownership, and that the relative proportions of insider and outsider ownership have remained surprisingly stable.

We used new survey data evidence in exploring how the ownership changes are taken place in practice. We made several new findings:

- Contrary to what is sometimes presented in the literature, employees do not rush to sell their shares. Share trade is rather infrequent; 
- Share issues play an important in reshaping ownership patterns;

- Attrition and failure to include new employees as owners is strongly reducing employee ownership;

- Share markets are heavily regulated and outsider investors are excluded from the share markets (and typically also new employees);

- Managers play a crucial role in shaping the ownership relations, and they substitute 'the market for enterprise control' by their authority.

Further, we explained why employee ownership in Eastern Europe has declined fast, while in developed economies no comparable declines have been observed. The rapid decline can be associated with privatisation process (employee ownership was intended to be transient only), with low employee representation, and with direct ownership structures. An important lesson from the Estonian experience is that it might be a bad idea to try to create employee ownership with direct share ownership. $^{22}$

Since there are in most cases no functioning market for shares and managers can substitute the price mechanisms by their authority, there is no guarantee the observed ownership changes are efficient. On the other hand, nothing in the analysis indicates that the initial ownership structures were superior. One can resolve this question only by analysing the pre- and post-change performance. More research on this is clearly needed.

There is yet relatively little comparative evidence from other transition countries. Generating such evidence would be important for policy prescriptions and in order to confirm the findings in this paper. In this process, incoming EU accession candidates can teach important lessons for the EU countries on how the implement successful and viable employee ownership schemes, or rather, how to avoid the worst mistakes. $^{23}$ 


\section{REFERENCES}

Aghion, Philippe and Olivier Blanchard (1998): 'On Privatisation Methods in Eastern Europe and Their Implications', Economics of Transition, 6:87-99.

Aghion, Philippe and Wendy Carlin (1997): 'Restructuring Outcomes and the Evolution of Ownership Pattern in Central and Eastern Europe', in Salvatore Zecchini (ed.): Lessons From the Economic Transition: Central and Eastern Europe in the 1990s, 241-261. Dordrecht: Kluwer Academic Publishers.

Andersen, Erik Andre (1997): 'The Legal Status of Russians in Estonian Privatisation Legislation', Europe-Asia Studies 49 (2): 303-16.

Anderson, James H., Georges Korsun, and Peter Murrell (1999): 'Ownership, Exit and Voice After Mass Privatization: Evidence from Mongolia', Economics of Transition, 7: 215-43.

Aoki, Masahiko (1995): 'Controlling Insider Control: Issues of Corporate Governance in Transitional Economies', in Aoki and Hyung-Ki Kim (eds.): Corporate Governance in Transitional Economies: Insider Control and the Role of the Banks, 329.

Benelli, Giuseppe, Claudio Loderer and Thomas Lys (1987): 'Labor Participation in Corporate Policy-Making Decisions: West Germany’s Experience with

Codetermination', Journal of Business, 60: 553-75.

Ben-Ner, Avner (1984): 'On the Stability of Cooperative Type of Organization', Journal of Comparative Economics, 8:247-260.

Ben-Ner, Avner (1988): 'The Life Cycle of Worker-owned Firms in Market Economies: a Theoretical Analysis', Journal of Economic Behavior and Organisation, 10:287-313.

Blair, Margaret (1999): 'Firm-specific Human Capital and the Theory of the Firm', in Blair and Roe (1999).

Blair, Margaret and Mark J. Roe (1999, eds.): Employees and Corporate Governance, Washington D.C.: Brookings.

Blanchard, Olivier and Philippe Aghion (1996): 'On Insider Privatization', European Economic Review, 40:759-766.

Blanchard, Oliver, Rudiger Dornbusch, Paul Krugman, Richard Layard and Lawrence Summers (1991): Reform in Eastern Europe, Cambridge, MA: MIT Press.

Blasi, Joseph Raphael (1988): Employee Ownership: Revolution or Ripoff?, Cambridge, MA: Harper and Row.

Blasi, Joseph R., Maya Kroumova and Douglas Kruse (1997), Kremlin Capitalism: Privatizing the Russian Economy, Ithaca: Cornell University Press. 
Blasi, Joseph and Andrei Shleifer (1996): 'Corporate Governance in Russia: An Initial Look', in Frydman, Gray and Rapaczynski (1996).

Blinder, Alan S. (1990, ed.): Paying for Productivity: A Look at the Evidence, Washington D.C.: Brookings.

Bowles, Samuel (1999): 'Endogenous Preferences: The Cultural Consequences of Markets and Other Economic Institutions', Journal of Economic Literature, 36 (1): 75-111.

Bowles, Samuel and Herbert Gintis (1993): 'The Democratic Firm: An AgencyTheoretic Evaluation', in Bowles, Gintis and Bo Gustafsson (eds), Markets and Democracy: Participation, Accountability and Efficiency, Cambridge University Press, pp. 13-39.

Bowles, Samuel and Herbert Gintis (1996): 'The Distribution of Wealth and the Viability of the Democratic Firm', in Ugo Pagano and Robert Rowthorn (1996, eds): Democracy and Efficiency in the Economic Enterprise, London, Routledge, pp. 8297.

Boycko, Maxim, Andrei Shleifer and Robert Vishny (1995): Privatizing Russia, Cambridge, MA: MIT Press.

Brown, Annette N. (1998): 'Worker Share Ownership and Market for Corporate Control in Russia', Western Michigan University Department of Economics working paper 96-23.

Chilosi, Alberto (1996): 'Distributional Consequences of Privatization in the Economies in Transition: An Analytical Framework', Moct-Most, 6:75-93.

Craig, Ben and John Pencavel (1992): 'The Behavior of Worker Cooperatives: The Plywood Companies of the Pacific Northwest', The American Economic Review, 82:1083-1105.

Dahl, Robert (1985): A Preface to Economic Democracy, Berkeley, CA: University of California Press.

Demzetz, Harold and Kenneth Lehn (1985): 'The Structure of Corporate Ownership: Causes and Consequences', Journal of Political Economy, 93: 1155-77.

Djankov, Simeon (1999): 'Ownership Structure and Enterprise Restructuring in Six Newly Independent States', Comparative Economic Studies, 41: 75-95.

Djankov, Simeon and Peter Murrell (2002 ): 'Enterprise Restructuring in Transition: A Quantitative Survey', Journal of Economic Literature 40 (3): 739-92.

Dow, Gregory K. (2003): Governing the Firm: Workers' Control in Theory and Practice, New York: Cambridge University Press. 
Dow, Gregory K. and Louis Putterman (2000): 'Why Capital Suppliers (Usually) Hire Workers: What We Know and What We Need to Know', Journal of Economic Behavior and Organization, 43: 319-336.

Earle, John S. and Saul Estrin (1996), 'Employee Ownership in Transition', in Frydman, Gray and Rapaczynski (1996).

EBRD (1998): Transition Report 1997: Enterprise Performance and Growth, London: European Bank for Reconstruction and Development.

Elenurm, Tiit and Erik Terk (1996): 'Employee Ownership in Estonia: Conclusions from Case Studies', in Niels Mygind (ed.): Privatisation and Financial Participation in the Baltic Countries, Copenhagen: Copenhagen Business School, 1-11.

Ellerman, David P. (1990): The Democratic Worker-Owned Firm, Boston: Unwin Hyman.

Estrin, Saul (1994, ed.): Privatisation in Central and Eastern Europe, Longman.

Estrin, Saul and Derek C. Jones (1992): 'The Viability of Employee-owned Firms: Evidence from France', Industrial and Labor Relations Review 45(2): 323-338.

Estrin, Saul and Adam Rosevear (1999): 'Enterprise Performance and Corporate Governance in Ukraine', European Economic Review, 27 (3): 442-58.

Estrin, Saul and Mike Wright (1999): 'Corporate Governance in the Former Soviet Union: an Overview', Journal of Comparative Economics, 27:398-421.

EU (2002): 'On a Framework for the Promotion of Employee Financial Participation', European Commission Communication 364 final.

Fitzroy, Felix R. and Kornelius Kraft (1987): 'Cooperation, Productivity, and Profitsharing', Quarterly Journal of Economics, 102 (1): 23-36.

Frydman, Roman, Cheryl Gray and Andrzej Rapaczynski (1996,eds): Corporate Governance in Central Europe and Russia, vol. 2: Insiders and the State. Budapest:CEU Press.

Frydman, Roman and Andrzej Rapaczynski (1994): Privatization in Eastern Europe: Is the State Withering Away? Budapest: Central European University Press.

Furubotn, Eirik and Svetozar Pejovich (1970): 'Property Rights and the Behaviour of the Firm in a Socialist State: the Example of Yugoslavia', Zeitschrift für Nationalökonomie, 30: 430-454.

Gordon, Jeffrey (1999): 'Employee Stock Ownership in Economic Transitions: The Case of United Air Lines', in Blair and Roe (1999). 
Hansmann, Henry (1990): 'When Does Worker Ownership Work? ESOPs, Law Firms, Codetermination, and Economic Democracy', The Yale Law Journal, 99: 1749-1816.

Hansmann, Henry (1996): The Ownership of Enterprise, Cambridge, MA: Belknap Press.

Jensen, Michael C. and William H. Meckling (1979): 'Rights and Production Functions: An Application to Labor-Managed Firm and Codetermination', Journal of Business, 52(4): 469-506.

Jones, Derek C. (1979): 'US Producer Co-operatives: The Record to Date', Industrial Relations, 18:342-357.

Jones, Derek C. (1998): 'The Economic Effects of Privatization: Evidence from a Russian Panel', Comparative Economic Studies, 40:75-102.

Jones, Derek C. and Niels Mygind (1999a): 'The Nature and Determinants of Ownership Changes After Privatization: Evidence From Estonia', Journal of Comparative Economics, 27: 422-441.

Jones, Derek C. and Niels Mygind (1999b): 'Ownership Patterns and Dynamics After Privatization in Transition Economies: Evidence From the Baltics', Baltic Journal of Economics, 2 (2): 99-140.

Jones, Derek C. and Niels Mygind (2000): 'Privatization and Enterprise Performance: Evidence from Estonia', in Milica Uvalic and Vojmir Franicevic (eds.), Equality, Participation, Transition: Essays in Honour of Branko Horvat, London: Macmillan.

Jones, Derek C. and Niels Mygind (2002): 'Ownership and Productive Efficiency: Evidence from Estonia', Review of Development Economics 6 (2): 284-301.

Kalmi, Panu (2000): 'Employment and Share Trade Under Employee Share Ownership: An Application for Transition Economies', Economic Analysis: Journal of Enterprise and Participation, 2000, 3 (1): 5-22.

Kalmi, Panu (2002a): On the (In)stability of Employee Ownership: Estonian Evidence and Lessons for Transition Economies, Copenhagen Business School Ph.D. thesis series 10.02

Kalmi, Panu (2002b): 'Does Employee Ownership Survive the Transition: Case Study Evidence From Estonia', Acta Oeconomica 52 (3): 307-25.

Kalmi, Panu and Niels Mygind (2003): 'Privatisation and Evolution of Ownership and Corporate Governance in Estonia - 12 Cases', mimeo, Center for East European Studies, Copenhagen Business School.

Kozarzewski, Piotr and Rick Woodward (2001): 'Secondary Privatisation in Poland (Part I): Evolution of Ownership Structure and Company Performance in Firms 
Privatized by Employee Buyouts', CASE Reports No. 47, CASE Foundation, Warsaw.

Kruse, Douglas L. and Joseph R. Blasi (1997): 'Employee Ownership, Employee Attitudes, and Firm Performance: a Review of the Evidence', in David Lewin, Daniel J.B. Mitchell and Mahmood Zaidi (eds.): The Human Resource Management Handbook, part I, Greenwich, CT: JAI Press, 113-52.

Lazear, Edward P. and Richard B. Freeman (1997): 'Relational Investing: the Worker's Perspective', in Roland Gilson, John C. Coffee and Louis Lowenstein (eds.): Meaningful Relationships: Institutional Investors, Relational Investing, and the Future of Corporate Governance, New York: Oxford University Press.

Liuhto, Kari (1995): 'Foreign Investment in Estonia: a Statistical Approach', EuropeAsia Studies, 47(3).

Liuhto, Kari (1996): 'Entrepreneurial Transition in Post-Soviet Republics: the Estonian Path', Europe-Asia Studies, 48 (1): 121-40.

Miyazaki, Hajime (1984): 'On Success and Dissolution of the Labor-managed Firm in the Capitalist Economy', Journal of Political Economy, 92: 909-931.

Mygind, Niels (1992): 'The Choice of Ownership Structure', Economic and Industrial Democracy, 13: 359-99.

Mygind, Niels (2000): 'Privatisation, Governance and Restructuring of Enterprises in the Baltics', OECD, Centre for Co-operation with non-members, working paper CCNM/BALT, 6, 1-83.

Mygind, Niels (2001): 'Enterprise Governance in Transition: A Stakeholder Perspective', Acta Oeconomica 51(3): 315-42.

North, Douglass C. (1990): Institutions, Institutional Change and Economic Performance, Cambridge, UK: Cambridge University Press.

Nuti, Domenico Mario (1995): 'Mass Privatisation: Costs and Benefits of Instant Capitalism', in Renzo Daviddi (ed.), Property Rights and Privatisation in the Transition to a Market Economy, Maastricht: European Institute of Public Administration.

OECD (1996): Estonia: Review of Agricultural Policies, Centre for Co-operation with the Economies in Transition, Organisation for Economic Co-operation and Development, Paris.

Pérotin, Virginie A. (1997): What Makes Coops Work? Institutional Viability, Firm Creation, Survival and Closure Among Workers' Cooperatives in France, Ph.D. dissertation, Department of Economics, Cornell University.

Pérotin, Virginie and Andrew Robinson (2003): 'Employee Participation of Profit and Ownership: A Review of Issues and Evidence', Luxembourg: European Parliament. 
Pohl, Gerhard, Robert E. Anderson, Stijn Claessens and Simeon Djankov (1997): 'Privatization and Restructuring in Central and Eastern Europe', World Bank Technical Paper No. 368.

Roland, Gerard (2002): 'The Political Economy of Transition', Journal of Economic Perspectives 16 (1): 29-50.

Rosner, Menachem (1985): 'Theories of Cooperative Degeneration and the Experience of the Kibbutz', Annals of Public and Cooperative Economics, 56(4): 527-538.

Russell, Raymond (1995): Utopia in Zion: The Israeli Experience With Worker Cooperatives, Albany, NY: State University of New York Press.

Shleifer, Andrei and Lawrence Summers (1988): 'Breach of Trust in Hostile Takeovers', in Alan J. Auerback (ed.): Corporate Takeovers: Causes and Consequences, Chicago: University of Chicago Press, 33-56.

Smith, Stephen C. (1988): 'On the Incidence of Profit and Equity Sharing: Theory and Application to the High Tech Sector', Journal of Economic Behavior and Organization 9: 45-58.

Smith, Stephen C. (2001): 'Blooming Together or Wilting Alone? Network Externalities and the Mondragon and La Lega Cooperative Networks', Discussion Paper Nr. 2001/27, WIDER, United Nations University, Helsinki.

Terk, Erik (1996): 'Employee Ownership and the Political Debate in Estonia 1987-1994', in Niels Mygind (ed.): Privatisation and Financial Participation in the Baltic States, vol. 1 Center for East European Studies, Copenhagen Business School, 95-122.

Terk, Erik (2000): Privatisation in Estonia: Ideas, Processes, Results, Tallinn: Estonian Institute for Future Studies.

Uvalic, Milica and Daniel Vaughan-Whitehead (1997, eds.): Privatization Surprises in Transition Economies, Cheltenham: Edward Elgar.

Uvalic, Milica and Daniel Vaughan-Whitehead (1997b): 'Introduction: Creating Employee Capitalism in Central and Eastern Europe', in Uvalic and Vaughan Whitehead (1997a). 
Table 1. Origin and ownership category at the time of privatisation

\begin{tabular}{|l|r|r|r|r|r|}
\hline & \multicolumn{1}{|c|}{$\begin{array}{c}\text { Former state } \\
\text { firms }\end{array}$} & \multicolumn{1}{c|}{$\begin{array}{c}\text { Former } \\
\text { collectives }\end{array}$} & \multicolumn{1}{c|}{$\begin{array}{c}\text { Former joint } \\
\text { ventures }\end{array}$} & New firms & Total \\
\hline Foreign & 9 & 1 & 30 & 48 & 88 \\
\hline $\begin{array}{l}\text { Domestic } \\
\text { outsiders }\end{array}$ & 33 & 46 & 3 & 34 & 116 \\
\hline Managers & 26 & 4 & 0 & 58 & 88 \\
\hline Employees & 38 & 16 & 0 & 18 & 72 \\
\hline Total & 106 & 67 & 33 & 158 & 364 \\
\hline
\end{tabular}

Source: Database on Estonian Enterprises at Center for East European Studies,

Copenhagen Business School.

Notes: This table includes firms that were private at the beginning of 1995 .

Rows indicate the dominant owner at the time of privatisation and the columns indicate the origin of the enterprise.

Table 2. Ownership changes between privatisation and beginning of 2001

\begin{tabular}{|l|l|l|l|l|l|l|}
\hline $\begin{array}{l}\text { Ownership } \\
\text { at } \\
\text { privatisation }\end{array}$ & $\begin{array}{l}\text { Employees } \\
2001\end{array}$ & $\begin{array}{l}\text { Managers } \\
2001\end{array}$ & $\begin{array}{l}\text { Domestic } \\
\text { investors } \\
2001\end{array}$ & $\begin{array}{l}\text { Foreign } \\
\text { owners } \\
2001\end{array}$ & $\begin{array}{l}\text { Former } \\
\text { employees } \\
2001\end{array}$ & $\begin{array}{l}\text { Total at } \\
\text { privatisation }\end{array}$ \\
\hline Employees & 12 & 12 & 10 & 2 & 11 & 47 \\
\hline Managers & 2 & 44 & 8 & 1 & 0 & 55 \\
\hline $\begin{array}{l}\text { Domestic } \\
\text { investors }\end{array}$ & 2 & 19 & 35 & 5 & 6 & 67 \\
\hline $\begin{array}{l}\text { Foreign } \\
\text { owners }\end{array}$ & 0 & 4 & 6 & 50 & 0 & 60 \\
\hline Total 2001 & 16 & 79 & 59 & 58 & 17 & 229 \\
\hline
\end{tabular}

Source: Database on Estonian Enterprises at Center for East European Studies,

Copenhagen Business School.

Note: rows indicate ownership at privatisation and columns ownership in 2001.

Table 3. Ownership changes in employee-owned companies

\begin{tabular}{|l|l|l|l|l|l|l|}
\hline $\begin{array}{l}\text { Beginning } \\
\text { of the } \\
\text { year }\end{array}$ & Employees & Manager & $\begin{array}{l}\text { Former } \\
\text { employee }\end{array}$ & $\begin{array}{l}\text { Domestic } \\
\text { investor }\end{array}$ & $\begin{array}{l}\text { Foreign } \\
\text { investor }\end{array}$ & $\begin{array}{l}\text { Liquidated } \\
\text { or no data }\end{array}$ \\
\hline 1995 & $51(70.8 \%)$ & 6 & 7 & 7 & 1 & 0 \\
\hline 1996 & $45(62.5 \%)$ & 10 & 11 & 6 & 0 & 0 \\
\hline 1997 & $27(38.0 \%)$ & 16 & 16 & 10 & 2 & 1 \\
\hline 1998 & $20(30.8 \%)$ & 16 & 13 & 13 & 3 & 7 \\
\hline 1999 & $15(25.0 \%)$ & 16 & 10 & 14 & 5 & 12 \\
\hline 2000 & $11(22.0 \%)$ & 9 & 15 & 12 & 3 & 22 \\
\hline 2001 & $12(25.5 \%)$ & 12 & 11 & 11 & 2 & 25 \\
\hline
\end{tabular}

Source: Database on Estonian Enterprises at Center for East European Studies, Copenhagen Business School.

Notes: Includes firms, in which employees were after privatisation the largest group of owners $(\mathrm{N}=72)$.

Beginning of the year situation 
Table 4. Trade of shares according to the group

\begin{tabular}{|l|l|l|l|l|}
\hline & Managers & Employees & $\begin{array}{l}\text { Former } \\
\text { employees }\end{array}$ & Outsiders \\
\hline $\begin{array}{l}\text { Sold shares } \\
(\mathrm{N}=16)\end{array}$ & 2 & 8 & 11 & 0 \\
\hline $\begin{array}{l}\text { Bought } \\
\text { existing shares } \\
(\mathrm{N}=16)\end{array}$ & 11 & 8 & 0 & 3 \\
\hline $\begin{array}{l}\text { Bought new } \\
\text { shares (N=14) }\end{array}$ & 9 & 3 & 0 & 3 \\
\hline
\end{tabular}

Source: Manager survey

Notes: Includes only firms where employees were dominant owners in 1996. Existing shares were traded in 16 enterprises and new shares were issued in 14 enterprises. Columns indicate which group has bought / sold shares. Multiple answers were permitted, therefore row totals are greater than the number of firm-observations.

Table 5. Main reason for ownership change $(\mathrm{N}=17)$

\begin{tabular}{|l|r|r|r|r|}
\hline & Share trade & Share issues & $\begin{array}{l}\text { Employee } \\
\text { turnover }\end{array}$ & \multicolumn{2}{|l|}{ Total } \\
\hline $\begin{array}{l}\text { Employees } \\
\text { managers }\end{array}$ & 2 & 3 & 1 & 6 \\
\hline $\begin{array}{l}\text { Employees } \\
\text { outsiders }\end{array}$ & 2 & 3 & 1 & 6 \\
\hline $\begin{array}{l}\text { Employees -> } \\
\text { former employees }\end{array}$ & 0 & 0 & 5 & 5 \\
\hline Total & 4 & 6 & 7 & 17 \\
\hline
\end{tabular}

Source: Manager survey

Note: Includes only firms that were in 1996 employee-owned and changed ownership category subsequently. 


\section{NOTES:}

${ }^{1}$ We define institutional environment following North (1990), meaning the set of rules that govern the actions the agents (including employees, management, investors) can take.

${ }^{2}$ For a highly original recent survey of the literature, see Dow (2003).

${ }^{3}$ This has been especially the idea behind the US ESOP-movement (see Blasi, 1988).

${ }^{4}$ In late 1980s worker councils were established as a response to a Moscow-initiated campaign, but they never constituted an important political force. They were widely regarded as tools of the Soviet authorities, and therefore lost credibility during the strive for independence (Terk, 1996).

${ }^{5}$ According to Russell (1995), it was Mill how coined the term 'degeneration' in relation to the decline of worker-controlled organisations in his Principles of Political Economy.

${ }^{6}$ This works in a slightly different way between in joint-stock companies than in co-operatives. Cooperatives that have variable equity capital may be compelled to maintain certain membership size in order to maintain its equity capital,. Joint-stock companies with "fixed" equity capital do not need new owners for that purpose, but they may appreciate equity financing through share issues that improves their financial position.

7 The evidence includes the studies of Blasi, Kroumova and Kruse (1997) and Jones (1998) on Russia, Djankov (1999) and Estrin and Wright (1999) on CIS countries, Anderson, Korsun and Murrell (1999) for Mongolia, Jones and Mygind (1999) for Estonia, and Kozarzewski and Woodward (2001) on Poland.

${ }^{8}$ In particular, we ignore here the substantial role foreigners have played in Estonian privatisation (Liuhto, 1995), small privatisation, entry of new firms and entrepreneurship (Liuhto, 1996), and the centralised privatisation programme (Terk, 2000). Mygind (2000) offers a balanced discussion on different developments in Estonian privatisation.

${ }^{9}$ Notice that since the centralised privatisation process was far from complete by 1995 , our sample leaves out a substantial number of enterprises that were privatised between 1995-1997. Therefore our sample cannot be taken to be representative of the entire privatisation process. However, since very few enterprises were privatised to employees after 1995, it captures very well the dynamics of employee ownership, which is the main focus of this paper.

${ }^{10}$ Although almost certainly more employee-owned firms were successors of former collective and state farms than of state-owned firms, state-owned firms were larger than the successor firms of collective farms, and therefore more likely to enter the stratified sample.

${ }^{11}$ It is possible that sometimes a firm that dates from the socialist period is mistakenly here classified as new. The classification is based on self-reporting by firms.

${ }^{12}$ Andersen (1997) stresses the impact of nationality policies and maintains that the Estonian privatisation policies were designed to favour ethnic Estonians, instead of ethnic Russians. However, it is difficult to determine how these arguments can be reconciled with the arguments here. For instance, there is evidence that when leasing was used, the entire workforce - including ethnic Russians became owners (Elenurm and Terk, 1996). Employee ownership can even be viewed as a method of alleviating the problems of ethnic divisions in privatisation.

${ }^{13}$ The decline may partly reflect the fact that when a firm is acquired by another domestic firm, it is often merged with the acquiring firm. This may be an explanation why firms owned by domestic investors are more likely to exit from the sample.

${ }^{14}$ Aghion and Blanchard also pointed out that employees can collude to prevent undesirable ownership changes and managers often have in their interest to support these collusions. The Estonian experience confirms this hypothesis.

${ }^{15}$ Some management interviews reported in Kalmi and Mygind (2003) revealed that at least some managers thought in this way: "ownership and decision-making are not the business of employees". Presumably, many employees would agree.

${ }^{16}$ In order to gain a certain level of shares (say, 50\%) one has to buy more new shares than in the case if one were buying existing shares, so this effect depends on the price difference between the price employees demand for their share and the price of new shares.

${ }^{17}$ Incidentally, this is very much in the same magnitude as the figures reported by Blasi and Shleifer (1996, p. 93) from Russia.

${ }^{18}$ As mentioned earlier in the text, the nominal values of shares correspond roughly to one month's salary. According to Dow (2003), the upfront investment in employee shares in US employee-owned firms can amount to 2-3 times annual salaries. This comparison gives also perspective on the extent of 
financing difficulties of employee-owned firms in developed market economies vis-à-vis transition economies.

${ }^{19} \mathrm{New}$ shares can be issued in return of individual contributions or from profits. The latter obviously does not change ownership structures, and they are not included here.

${ }^{20}$ This issue comes out clearly from the case studies of Kalmi (2002b), who finds from a sample of employees in Estonian employee-owned firms that 3 of our of 4 employees who had been employed at the time of privatisation was still owning shares several years after privatisation, while of new employees only 1 in 8 was owning shares.

${ }^{21}$ Notice that this is not the transitional purpose that Aghion and Blanchard endorse: they would like to see transitions to investor ownership.

${ }^{22}$ For alternative blueprints that are consistent with the view presented here, see Ellerman (1990) and Dow (2003).

${ }^{23}$ This issue is especially relevant given the Commission's strong endorsement for financial participation schemes; see EU (2002). 